\title{
0 kvalitě a hodnoticích kritériích akčního výzkumu
}

\author{
Małgorzata Kaliszewska
}

Univerzita Jana Kochanowského v Kielcích

Akční výzkum stále nemá v metodologii stabilizovanou pozici. Jeho minulost prokazuje velký praktický př́nos v procesu zavádění změn, ale i problémy v dosahování ukazatelů vědeckosti - tento fakt byl zdůrazňován zejména v období dominance pozitivistického paradigmatu a tradiční metodologie. V USA to vedlo až k opuštění této metody, ovšem spolu s rozvojem kvalitativních výzkumů, po lingvistickém obratu a rozvoji narativních výzkumů se opět začala rozvíjet v Anglii. Bývá zdůrazňováno také odtržení akčního výzkumu od filozofické tradice (praktická filosofie - praxis) a nahrazení této filozofie metodologií společenských věd (Carr, 2010; Wallace, 1987; McTaggart, 1991).

Jak konstatuje Newby, akční výzkum vznikl z potřeby zmenšit vzdálenost mezi scientistickou tradicí výzkumů a školní praxí (Newby, 1997). Pro nás představuje především typ kvalitativního pedagogického výzkumu, protože právě v této oblasti se projevuje jeho vědecký přínos a uplatnění.

\section{Diskuse o kritériích kvality a teoretických východiscích kvalitativních výzkumů}

V době rozvoje kvalitativních výzkumů, které se pro nás dnes mohou stát zdrojem neustálé inspirace ve vztahu ke kritériím akčního výzkumu, se pro ně užívaly tradiční termíny hodnoticích kritérií výzkumu, tj. objektivita, správnost a přesnost, ačkoli specifická podstata kvalitativních výzkumů neumožňuje jejich splnění (Urbaniak-Zając, 2006). Těmto názvům se sice přiřazovaly nové obsahy, ale zmíněná kritéria, vycházející z naturalismu, nemohla mít univerzální užití (Miles \& Huberman, 2000). Objektivity nebylo možné dosáhnout přinejmenším proto, že badatel i zkoumané osoby jsou chápáni jako „reflektivní účastníci v daném společenském kontextu“ (Miles \& Huberman, 2000). Správnost výsledků by pak vyžadovala relativní stálost zkoumaných jevů a možnost jejich rekonstrukce, což je v pedagogických výzkumech problematické (např. rozhovor) (Steinke, 1999). Přesnosti by pak bylo možné dosáhnout izolováním proměnných, což se v komplexních 
kvalitativních výzkumech nedělá, navíc nelze zobecňovat výsledky výzkumů z důvodu nenáhodného výběru zkoušky (Miles \& Huberman, 2000). To vše dokládá neadekvátnost těchto kritérií v kvalitativních výzkumech, ačkoli je řada vědců i nadále považuje za ukazatele, kterých by se měla držet (Miles \& Huberman, 2000). Objevovaly se a stále se objevují nová kritéria, legitimizující vědeckost kvalitativních výzkumů a reagující na potřeby výzkumné praxe. Populární se staly např́íklad různé variace triangulace Denzina (Denzin, 1989), ačkoliv v pozdějších pracích Denzin triangulaci chápe spíše jako strategii získávání nových poznatků než jako záruku větší přesnosti nebo objektivity (Flick, 2011). Existuje rovněž skupina vědců, která se domnívá, že univerzální kritéria neexistují, protože nelze analyzovat výsledky odděleně od osob a procesů, a není tedy možné vytvořit společný systém hodnocení (Steinke, 2000). Jak uvádí Urbaniak-Zając (in Steinke, 2000), v názorech řady autorů se objevují vlivy poststrukturalismu a je zdůrazňován význam jazyka pro konstrukci zkoumaného předmětu.

Podle Flicka si dnešní otázky po kvalitě kvalitativních výzkumů už nekladou za cíl poukázat na problém absence jejich vědecké hodnoty, ale spíše prokázat vědecké kvality užívaných postupů. Tyto otázky jsou zároveň spojeny s výzkumným procesem (Flick, 2011). Vnitřní potřebou kvalitativních badatelů tváří v tvář širokému spektru již vyzrálých kvalitativních metod se stalo nalezení kritérií kvality každého přístupu a porovnání jejich kvality a účinnosti. Výzvou současnosti je hledání těchto kritérií pro potřeby vědců, kteří se díky nim chtějí lépe připravit na vnější hodnocení své činnosti, institucí hodnoticích kvalitu podaných vědeckých projektů a udělujících granty, redakcí časopisů, které potřebují kritéria pro výběr textů pro publikaci, a čtenářů, kteří se chtějí seznámit s kritérii hodnocení popisovaných výzkumů (Flick, 2011).

Jak se domnívá Flick (2011), alternativou k formulování kritérií kvality se mohou stát strategie usilující o různorodost, protože otevření výzkumného procesu různorodosti, jeho elastičnost a spojení s konkrétními problémy mohou být pro kvalitu důležité. A tak se různorodost na úrovni teoretického sbírání vzorků, analýzy vzorků nevhodných a přístupu k odlišným názorům stává - díky snaze o potvrzení ze strany zkoumaných - strategií zvyšující kvalitu výzkumu.

Např. Steinke navrhuje následující kritéria kvalitativních výzkumů (in Urbaniak-Zając, 2006): (a) umožnění intersubjektivní rekonstrukce prů- 
běhu vědeckého procesu (podrobná dokumentace, popis dynamiky vztahů badatele a zkoumaných, popis vědeckých východisek atd.), analýza vědeckého procesu je možná také během skupinové interpretace faktů; (b) kontrola adekvátnosti vědeckého postupu ve vztahu ke zkoumané otázce; (c) empirické ukotvení teorie a její empirická kontrola; (d) tematizace hranic platnosti výsledků; (e) reflexe subjektivity; (f) vnitřní shodnost (srov. Flick, 2002).

Vědci se také pokoušejí nalézt teoretické základy pro kritéria kvalitativních výzkumů. Takové ukotvení můžeme hledat v konstruktivismu „chápaném ne jako konkrétní teorie, ale jako perspektiva vidění světa, která je blízká perspektivě kvalitativních výzkumů“, jak se domnívá Steinke (1999).

Je ovšem neetické vybírat kritéria a strategie nikoliv podle typu výzkumu, ale podle následné užitečnosti pro vědce, např. tak, aby byla shodná s kritérii užívanými v procesu recenzování článku určeného k otištění v prestižním časopise.

Z tohoto krátkého shrnutí vyplývá, že kritéria kvality široce pojatých kvalitativních výzkumů vyplývají na jedné straně z pocitu odpovědnosti a vědecké poctivosti badatele, na straně druhé jsou závislá na mimovědeckých zájmech skupiny, snahy o povýšení, osobní úspěch a plnění závazku „získávat body".1

\section{Specifika akčního výzkumu ve vztahu k požadavkům jejich kvality}

Termín akční výzkum (polsky „badania w działaniu“) se v polštině používá od přelomu 80. a 90. let 20. století a je překladem spojení action research. V současné době již neodráží - podle redaktorek dnes nejrozsáhlejší práce na toto téma v polštině (Červinková \& Golebniak, 2010) - evoluci tohoto přístupu. Jazykový úzus však způsobuje, že tento termín nelze z literatury vymýtit. Akční výzkum je „organizační forma výzkumu, která pomáhá změnit praxi, v níž realizátor (učitel, sociální pracovník, šéf organizace atd.) je zároveň badatelem i organizátorem změny" (Czerepaniak-Walczak, 2010). Tato definice nezdůrazňuje kvalitativní charakter tohoto výzkumu, ačkoli je považován za navýsost kvalitativní a interpretativní (existují ovšem i takové, které vyžadují široký kvantitativní výzkum) (Czerepaniak-Walczak, 2010). Bohatá

Můžeme zde diskutovat o tom, nakolik jsou tyto body faktickým vědeckým zájmem pedagogických univerzit. 
a dynamická historie tohoto metodologického jevu dokazuje jeho užitečnost a životnost, i přes všechna omezení, výhrady a nenaplňování tradičně závazných nároků vědeckosti (Kaliszewska, 2010). Nemáme zde bohužel prostor pro jejich širší představení a není to ani cílem tohoto článku, je však nutné říci, že tento výzkum může napomoci rozvoji vědy jiným zpo̊sobem než pozitivistické metody. Pro naše hlavní téma je důležité, že tento druh výzkumu umožňuje například analýzu vyvíjejících se kritérií, potřebných pro popis a hodnocení činnosti v organizačním kontextu (Červinková \& Golebniak, 2010).

V akčním výzkumu byla kritéria kvality empirického výzkumu zastoupena novými kvalitativními kritérii. Např. Moser (1997) navrhl následující: (a) transparentnost jako možnost analýzy daného výzkumného procesu všemi účastníky, tedy prezentace funkcí, cílů a metod výzkumné práce; (b) shodnost, potvrzující jednotu cílů a metod výzkumné práce; (c) vliv vědce, který při sběru dat nesmí ovlivňovat výzkumný proces (Moser, 1977).

Podle Czerepaniak-Walczakové se důkazem péče o kvalitu akčního výzkumu musí stát triangulační přístup, tedy teoretická nebo metodologická triangulace nebo triangulace vědců. $Z$ pohledu vědecké objektivity by byla užitečná mnohonásobná triangulace. „Zaručuje to z jedné strany mnohost perspektiv náhledu na zkoumaný jev / zkoumané jevy a rozšiřuje zásobu dat, ze strany druhé to umožňuje skutečnou diskusi s použitím širokého spektra argumentů z různých teoretických perspektiv a praktických potřeb“" (CzerepaniakWalczak, 2010).

Hodnoticí kritéria kvality akčního výzkumu by měla zohledňovat jejich druh, dosah, angažovanost a význam, zejména pak originalitu a užitečnost jejich obsahu. Hlavním zdrojem kritérií by měly být na prvním místě znalosti vědce, teprve poté zájmy univerzity a vnějších organizací.

\section{Dilemata hodnocení kvality akčního výzkumu na př́kladu vysokoškolské didaktiky}

\subsection{Proces učení se během výzkumu}

Každá univerzita má trochu jinou organizaci a zvyky, proto naše závěry není možné zobecňovat. $V$ prủběhu akčního výzkumu se proces učení realizuje sbíráním zkušeností (Torbert, 1972), během školení účastníků (Lewin in Červinková \& Gołębniak, 2010) a sebevzděláváním. Podle Lewina se tento 
proces neuskuteční, nejsou-li prezentovány objektivní standardy výsledků. „Pokud nejsme schopni zhodnotit, zda je daná aktivita postupem či regresí, pokud chybí kritéria evaluace závislosti vloženého úsilí na výsledcích, nic nás nezachrání před chybnými závěry a posílení nesprávných pracovních návykư" (Červinková \& Golebniak, 2010).

Učení (se) je dynamické a rozvíjí se stejně jako vědecký proces, který neustále prověřujeme a můžeme i měnit východiska, modifikovat nebo měnit nástroje, a dokonce i upustit od některých výzkumů, pokud se setkají s odmítnutím zkoumaných (Krüger, 2008). Můžeme se v této souvislosti ptát na nejvhodnější moment kontroly těchto vědomostí, které přece $\mathrm{v}$ některém bodě mohou být neúplné, či dokonce mylné, a na cíle a kritéria hodnocení vědomostí, získaných v konkrétním okamžiku. Co prověřuje výsledky procesu učení (se) během akčního výzkumu? A měli bychom dopředu předvídat jeho výsledky? Otázka druhá: měli bychom proces učení se evaluovat a hodnotit už po první etapě výzkumu? Neměli bychom počkat na skončení celého výzkumného projektu, např. po třech letech, nebo zůstat u evaluace bez hodnocení? Za třetí: co by dnes mělo být důležitější v procesu akčního výzkumu: proces dosahování cíle, interpretace skutečnosti a konstruování nových významů, nebo jen viditelné a určitým způsobem měřitelné konečné výsledky výzkumu?

\subsection{Změna - jako cíl akčního výzkumu}

Cílem akčního výzkumu je změna nejen v oblasti vědomostí, ale také v samotném společenství (Kaliszewska, 2010). Hodnocení probíhajících změn by mělo vycházet $\mathrm{z}$ badatelem zvolené teorie změny. Podle Lewina přichází změna podle schématu: rozmrazování, akce-proměna, zmrazování (Czerepaniak-Walczak, 2010). V tomto kontextu by se aplikovaná změna měla projevit ihned „, plné kráse“. Ovšem vždy tomu tak není. Je to důkazem neúspěchu, neschopnosti nebo nedbalosti vědce? Hodnocení takové stavu mohou být př́isná.

Kanadský teoretik změny Fullan se domnívá, že osvětová změna „je jevem technicky jednoduchým, ale společensky neobvykle složitým" (Fullan, 1977). Uvádí až devět činitelů ovlivňujících zavedení změny (Fullan, 1977). Aby byly změny úspěšně zavedeny, musíme poznat podmínky, které je nutné splnit, aby proces změny mohl proběhnout, a to co nejsprávněji. Autor opouští plánovanou změnu a tvrdí, že žádná strategie a žádný počet inovací nezaručuje bezprostřední úspěch při zavádění změny. Podle jeho názoru je nezbytné 
přizpůsobit organizační situaci změně odpovídajícím personálním zajištěním a materiálními prostředky. Změna je vždy procesem chaotickým a lze jen těžko předvídat její důsledky (Fullan, 1977).

V amerických výzkumech (i v akčním výzkumu) se uplatnil tzv. „doceňující výzkum" (Appreciative Inquiry - AI). Patř́i do skupiny metod, které mohou doplňovat metodu „vyřeš-problém“ jako př́ístup k plánování a práci vedoucí ke změně, vyhodnocující nejlepší z toho, „co je“, jako výchozí bod pro realizaci vize toho, „,o by mohlo být“. Vychází ze spolupráce a spoluúčasti při hledání pozitivních sil, které můžeme objevit uvnitř jakéhokoli systému. Tzv. „doceňující výzkum" na počátku rozvíjeli David Cooperrider a Suresha Srivastave $\mathrm{z}$ Weatherhead School of Management, Case Western Reserve University (Cooperrider, nedat). Poté se tato metoda začala používat mimo soukromý sektor, rovněž ve vzdělávacích institucích (Braun, 2010). V návaznosti na to bychom se při volbě kritérií kvality a hodnocení změny - jako výsledku akčního výzkumu - měli vědomě řídit východisky dříve přijaté teorie změny.

\subsection{Kooperace nebo individuální práce?}

Ne vždy existuje na univerzitě dostatečně velká a sehraná skupina, která by jednomyslně navrhla změnu ve vysokoškolské didaktice a členové by spolupracovali na jejím zavedení a zároveň vedli akční výzkum. Dokonce i v takovém případě je kooperace obtížná z časových a organizačních důvodů a vyžaduje čas, trpělivost, vzájemné pochopení a především - schopnost dialogu a omezení rivality. Výzkumy vedené individuálně jsou vždy zatíženy větším rizikem chyby a menší působností myšlenky v domácím prostředí, ačkoli rozhodování je pro vědce pohodlnější. Hodnoticí kritéria obou však musejí být rozdílná, $\mathrm{v}$ prvním př́ípadě mají zdůrazňovat kooperaci a ve druhém individuální snahu. Každý vědecký přístup má totiž v procesu zvyšování kvality práce na univerzitě svůj význam. Odlišný je také dosah výzkumu a jeho programu a očekávané důsledky, které by kritéria měla rovněž zohledňovat.

\subsection{Strategie péče o kvalitu akčního výzkumu}

Triangulace je jednou ze strategií zvyšování kvality akčního výzkumu. Triangulace vědců a metod (a ještě jiné varianty této procedury) již jsou v odborné literatuře popsány (Flick, 2011), ale stále je zveřejněno př́liš málo konkrétních př́kladů jejich realizace na polské půdě, jejich kritického zhodnocení a závěrů. Hodnoticí kritéria musejí předcházet příklady úspěšné 
realizace podobného výzkumu, aby bylo zřejmé, čeho je možné dosáhnout, a čeho ne.

Dobře připravená dokumentace, objektivní článek nebo kniha - které se stanou základem hodnocení - vyžadují vysoké autorské kompetence, aby vědeckou námahu nezakryl její neobratný popis. Autorské kompetence budoucích aktivních vědců vyžadují tedy cvičení, stálou čtenářskou obec a zvyšující se kritické dispozice, které jsou kritériem kvality přípravy na zahájení badatelské činnosti.

\subsection{Cyklická spirála - reflexe a hodnocení etap učení se a provádění změn}

Specifickou vlastností akčního výzkumu je - podle termínu Lewina - cyklická spirála nebo spirála autoreflexe, případně fáze výzkumného cyklu. Vždy se také objevuje - více či méně výrazně - myšlenka hermeneutického kruhu (Pilch \& Bauman, 2001). V současné době by se nejvíce blížilo dynamice změn schéma (namísto spirály, schodů nebo rozvětvení) spirály spirál Jeana McNiffa (Czerepaniak-Walczak, 2010). Lze předpokládat, že jedna fáze, jeden kruh (nebo skupina kruhů na jedné úrovni) se časově kryje se školním rokem nebo akademickým semestrem.

Je však nutné zdůraznit, že univerzita se organizačně liší od škol nižšího vzdělávacího stupně. Zatímco např́íklad na základní škole učitelé-badatelé mohou vést skupinové výzkumy vybraných tříd po několik let za sebou, na vysoké škole to není možné s ohledem na semestrální systém studia, kde pracovníci jedné katedry mají přednášky a semináře v určitém časovém období, např. v prvním nebo druhém semestru prvního ročníku, a později již ztrácejí studenty $\mathrm{z}$ očí. $\mathrm{V}$ této situaci lze výzkum vést pouze $\mathrm{v}$ krátkém časovém období jednoho semestru, což je málo pravděpodobné, nebo „štafetově“, kdy vědci spolupracují s pedagogy z jiných kateder, kteří v dalších etapách studia s vybranou skupinou pracují, a chtějí se do výzkumu zapojit a pokračovat $\mathrm{v}$ něm $\mathrm{v}$ další etapě. $\mathrm{V}$ př́padě takových výzkumů se tým vědců rozšiřuje jako kruhy na vodě a získávání znalostí a zavádění změn se stává „echem“ prvotní koncepce. Následují pak krok po ní, tj. badatelé z nové etapy mají většinou povědomí o prvním okruhu, zatímco badatelé z první etapy už v té době procházejí třetím kruhem zasvěcení. „Spirály spirál“ mají potom menší průměr a jsou více či méně zploštěné, což může znamenat nízký nárůst znalostí a zavedených změn a stát se příčinou znechucení, oslabení motivace a - co je s tím spojené - nízkého hodnocení kvality výzkumu v budoucnosti, 
pokud hodnotící nezná dobře specifikum výzkumu vedeného v rámci vysokých škol. Podobný hybridní přístup, který umožňuje vést výzkum, nezjednodušuje tedy jeho evaluaci a hodnocení.

V případě první, základní etapy výzkumu, která je nejdynamičtější a nejzatíženější nedokonalostmi, by bylo správné provádět pouze evaluaci, a to „vnitřní“ či autoevaluaci, a zdržet se přitom hodnocení výsledků, protože podle Fullanovy teorie musí být na změnu dostatek času. Hodnocení celého projektu by mělo nastat až po jeho skončení, tedy po několikaletém období. Během každé etapy je však nutná silná podpora ze strany vedení pracoviště. Není také dobře, pokud vnější hodnocení přichází příliš brzy, protože mủže narušit sám proces a křivdit vědcům, snižovat jejich motivaci a odvahu zavádět změny, pokud se hodnocení neshoduje s pocity badatelů. Př́liš vysoké hodnocení potom oslabuje pozornost, ačkoli může zvýšit motivaci k práci.

Všechny snahy o zlepšení procesu vzdělávání učitelů a pedagogů, zejména změny paradigmatu na konstruktivistický, zlepšování komunikačních, kritických a emancipačních kompetencí studentů si zasluhují pozornost, podporu a svědomitý přístup $\mathrm{k}$ vnějšímu hodnocení akčního výzkumu, který se věnuje didaktickým otázkám. Je to samozřejmě jen jeden příklad možného akčního výzkumu na univerzitní půdě.

\section{Závěr}

Hodnoticí kritéria pedagogického akčního výzkumu neexistují jako specificky definovaná kategorie, již stačí poznat a použít. Vyžadovala by tedy první zpracování na základě zkušeností vědců. Domnívám se, že pro vlastní potřebu může badatel v této situaci z existujícího „katalogu“ vybrat nebo adaptovat individuální kritéria odpovídající konkrétním vedeným výzkumům.

Ti, kteří se chystají hodnotit průběh výzkumů a jejich výsledky, stojí před několika výzvami: (1) potřebou reflektovat své vlastnosti jako kritika, pokud přijmeme tezi Teresy Bauman (2006), že kritika můžeme charakterizovat jako adaptačního, emancipačního nebo hermeneutického, a (2) před výzvou citlivého problému volby kritérií tohoto hodnocení na základě zmiňovaných preferencí a jejich cílů. Je nezbytné uvědomit si hrozby plynoucí z výběru kritérií neadekvátních $\mathrm{k}$ typu výzkumu, což může vést $\mathrm{k}$ jeho nesprávnému hodnocení a vyžaduje od hodnotícího v tomto směru určitou pokoru. Navíc: (3) povědomí o specifice výzkumů a poté i - (4) reflexi. To znamená, že 
badatel, zkoumaní a ti, kteří hodnotí proces „zvenčí“, by měli tvořit „kruh zasvěcených“, mluvit „stejným jazykem“, vycházet ze stejného paradigmatu a mít podobnou metodologickou a společenskou citlivost, která umožňuje podobným způsobem vnímat svět a problematizovat ho. Napětí vzájemné „neadekvátnosti“, které se může objevit mezi ředitelem školy a učitelem nebo mezi učitelem, který vede akční výzkum, a jeho vědeckými vedoucími, se může stát zdrojem konfliktu, zejména pak na vysoké škole, kde se mohou střetnout různorodé paradigmatické přístupy, různorodá kritéria a osobní zkušenosti vědců. Podstatnou otázkou je (5) schopnost formulovat kritickou, ale konstruktivní zpětnou vazbu, jež následně obohacuje další etapy snahy o kvalitu vedeného výzkumu a (6) etický rozměr hodnocení cizího úsilí. Při vědomí postupné standardizace všech aspektů fungování vysokých škol bychom si měli nechat nějakou oblast svobody pro tvůrčí pochyby, reflexi a intuitivní, individualizované hodnocení, zejména pak v situaci řešení netypických, nových problémů.

V akčním výzkumu probíhajícím v rámci instituce mohou „vnitřní“ hodnoticí kritéria jeho kvality vyplývatz norem vysokéškoly, její kultury a tradice. Kvalita výzkumu by pak představovala vykročení mimo tyto normy (emancipace) nebo jejich ještě větší dodržování (adaptace). Nejtěžší situace pro badatele přichází v okamžiku, kdy tyto výzkumy nejsou chápány jako potenciální zájem školy, ale jako osobní zájem badatele, který je sotva tolerován; jako narušení stávajícího řádu. Akční výzkum pronikne do povědomí pedagogů a jejich didaktické praxe pouze $\mathrm{v}$ př́ípadě, že budou podobná kritéria stanovena, respektována a dodržována $\mathrm{v}$ procesu hodnocení jejich kvality a zároveň budou mít především „vnitřní“, tj. individuální charakter, odpovídající tomuto typu výzkumu a výsledkům očekávaným vědci a univerzitou, ne pouze charakter „vnějšíi, který slouží standardizaci pro vnější hodnocení výsledků výzkumu nebo jiným cílům.

\section{Literatura}

Bauman, T. (2006). Badacz jako krytyk. In D. Kubinowski \& M. Nowak (Eds.), Metodologia pedagogiki zorientowanej humanistycznie. Kraków: Of. Wyd. Impuls.

Braun, A. R. (2010). Approaches 16 - Beyond the problem-solving approach to sustainable rural development. Dostupné z http:// www.idrc.ca/en/ev-85089-201-1-DO_TOPIC.html

Carr, W. (2010). Filozofia, metodologia i badania w działaniu. In H. Červinková \& B. D. Gołębniak (Eds.), Badania w działaniu. Pedagogika i antropologia zaangażowane. Wrocław: Wyd. Nauk. DSW. 
Červinková, H., \& Gołębniak, B. D. (Eds.). (2010). Badania w działaniu. Pedagogika i antropologia zaangażowane. Wrocław: Wyd. Nauk. Dolnośląskiej Szkoły Wyższej.

Cooperrider, D. L. (nedat.) The child as agent of inquiry. Dostupné z http:// appreciativeinquiry. case.edu/uploads/Child-as-Agent.pdf

Czerepaniak-Walczak, M. (2010). Badanie $w$ działaniu. In S. Palka (Ed.), Podstawy metodologii badań w pedagogice. Gdańsk: GWP.

Denzin, N. (1989). The research act. Englewood Cliffs: Prentice-Hall.

Flick, U. (2002). Qualitative Sozialforschung. Reinberg bei Hamburg: Rowohlt.

Flick, U. (2011). Jakość w badaniach jakościowych. Warszawa, Nauk. PWN.

Fullan, M. (1997). Czynniki warunkujące skuteczność wprowadzania zmian. In D. EkiertGrabowska (Ed.), Współczesne tendencje w kierowaniu zmianq edukacyjną. Antologia II. Warszawa: Instytut Technologii Eksploatacji.

Kaliszewska, M. (2010). Badania w działaniu (action research) jako strategia dokonywania zmian w szkole wyższej: historia, podstawy teoretyczne i własny projekt badań. In K. Denek, A. Kamińska, W. Kojs, \& P. Oleśniewicz (Eds.), Edukacja jutra. Edukacja w społeczeństwie wiedzy. Sosnowiec: Wyższa Szkoła Humanitas.

Krüger, H. H. (2008). Metody badań w pedagogice. Gdańsk: GWP Gdańskie Wydawnictwo Psychologiczne.

Lewin, K. (2010). Badania w działaniu a problemy mniejszości. In H. Červinková \& B. D. Gołębniak (Eds.), Badania w działaniu. Pedagogika i antropologia zaangażowane. Wrocław: Wyd. Nauk. Dolnośląskiej Szkoły Wyższej.

McTaggart, R. (1991). Action research: A short modern history. Geelong: Deakin University Press.

Miles, M. B., \& Huberman, A. M. (2000). Analiza danych jakościowych. Białystok: Wyd. TransHumana.

Moser, H. (1977). Methoden der Aktionsforschung. München: Kösel.

Newby, M. J. (1997). Educational action research: The death of meaning? The practitioner's response to utopian discourse. Educational Research, 39(1), 77-86.

Pilch, T., \& Bauman, T. (2001). Zasady badań pedagogicznych. Strategie ilościowe i jakościowe, Warszawa: Wyd. Ak. „Żak“.

Steinke, I. (1999). Kriterien qualitativer Forschung, Weinheim: Juventa Verlag.

Steinke, I. (2000). Geltung und Güte. Bewertungskriterien für qualitative Forschung. In K. Kreimer (Ed.), Die Fallrekonstruktion. Sinnverstehen in der sozialwissenschaftlichen Forschung. Frankfurt a. M.: Suhrkamp Verlag.

Torbet, W. R. (1972). Learning from experience. New York: Columbia University Press.

Urbaniak-Zając, D. (2006). W poszukiwaniu kryteriów oceny badań jakościowych. In D. Kubinowski \& M. Nowak (Eds.), Metodologia pedagogiki zorientowanej humanistycznie. Kraków: Of. Wyd. Impuls.

Wallace, M. (1987). A historical review of action research: Some implications for the education of teachers in their management role. Journal of Education for Teaching, 13(2), 97-115. 